\title{
Optimal taxation with home production
}

\author{
Conny Olovsson* \\ Sveriges Riksbank \\ February 14, 2014
}

\begin{abstract}
Optimal taxes for Europe and the U.S. are derived in a realistically calibrated model where agents buy consumption goods and services, and use home capital and labor to produce household services. The optimal tax rate on services is substantially lower than the tax rate on goods. Specifically, the planner cannot tax home production directly and instead lowers the tax rate on market services to increase the relative price of home production. The optimal tax rate on the return to home capital is strictly positive, and the welfare gains from switching to optimal taxes are large.
\end{abstract}

JEL classification: D13; H21; J22

Keywords: Optimal Taxation, Household Production, Time Allocation, Labor Supply

\footnotetext{
${ }^{*}$ Sveriges Riksbank E-mail address: conny.olovsson@riksbank.se. I am grateful for comments from Christopher Sleet and one anonymous referee. All remaining errors are, of course, my own.
} 


\section{Introduction}

By now, it has become quite well established that the amount of market work differs substantially across countries. For instance, people in the U.S. work from 30 to 50 percent more per person than people in European countries, such as France, Germany and Belgium. ${ }^{1}$ One explanation that has been offered for these differences is that taxes distort the margin between labor and other activities. $^{2}$ Specifically, taxes distort not only the margin between market work and leisure, but also households' margin between buying market-produced services and home production. Several recent papers argue further that the high tax rates in Europe could be one reason for the failure of the European service sector to develop in the same way as in the U.S. ${ }^{3}$ When faced with high taxes on labor, goods and services, Europeans work relatively few hours in the market, and instead satisfy a larger share of their demand for services through home production.

Against this background, the objective of this paper is to analyze optimal tax policy in a fully dynamic setting where a representative agent takes decisions on how to allocate her income between consumption goods, market services and savings, and how to allocate her time between market work, home production and leisure. Home-produced services are imperfect substitutes for market services and they are produced by combining labor and home capital (which is regarded as consumer durables and housing). This setup captures the fact that households can choose between going to restaurants or cooking at home, between painting their own house or paying someone else to do it, etc. ${ }^{4}$

\footnotetext{
${ }^{1}$ The numbers are computed for people aged 15-64, and the source is EU KLEMS (2009).

${ }^{2}$ See Prescott (2004), Rogerson (2008), Ragan (2005), and Olovsson (2009).

${ }^{3}$ Papers that argue along this dimension include Freeman and Schettkat (2002), Rogerson (2008), Ragan (2005), Ngai and Pissarides (2008) and Olovsson (2009).

${ }^{4}$ The same margin generally does not exist for consumption goods. Most people would not consider producing their own cars, computers or cell phones because they find the cost disproportionate.
} 
The analysis follows Ramsey (1927), in the sense that the social planner chooses an optimal tax structure in an economy with a representative agent when only distortionary taxes are available. For a given tax rate on consumption goods, the tax instruments that the planner has at his/her disposal are taxes on industrial capital, home capital, labor and services. Tax policy is restricted in that leisure and hours spent in home production cannot be taxed.

The first and theoretical part of the paper shows that the well-known Atkinson-Stiglitz (A-S) separability theorem only applies in the knife-edge case when the elasticity of substitution between home and market services $(\varepsilon)$ is exactly equal to one. Specifically, the A-S theorem states that commodity taxes should be uniform across goods and services if the utility function is separable between labor and all commodities. ${ }^{5}$ When the elasticity is equal to one, preferences are weakly separable between all traded commodities and labor and this is sufficient for the A-S theorem to apply. Commodity taxes should then be uniform across goods and services.

For elasticities different from one, however, the fact that home production requires time as an input implies that preferences no longer are weakly separable between traded commodities and labor. The marginal rate of substitution between market-produced services and consumption goods then depends on the amount of home hours supplied, and home hours depend directly on the amount of labor supplied. Consequently, the A-S theorem does not apply and the optimal tax rate on market services should instead internalize the interdependency between home and market services. Specifically, the optimal tax on services should be lower (higher) than the tax on goods when home and market services are substitutes (complements). Intuitively, the first best requires uniform taxation of all commodities, including leisure and home production. Since all traded goods and services are equally substitutable for leisure, it is not possible to use non-uniform taxation to

\footnotetext{
${ }^{5}$ See Atkinson and Stiglitz $(1972,1976)$.
} 
tax leisure. When home and market services are substitutes, however, a reduction in the tax rate on market services is equivalent to a tax on home production, since it increases the relative price of home production. When the two types of services are instead complements, a tax on market services is equivalent to a tax on home production because the two types of services are then consumed together. ${ }^{6}$

The logic is similar for the optimal tax on home capital. When $\varepsilon=1$, the A-S theorem holds and the implied tax on the total return to home capital is zero. ${ }^{7}$ When $\varepsilon \neq 1$, however, a marginal unit of accumulated home capital also influences the demand for market services in subsequent periods. This effect is ignored by the agent and the optimal tax rate should adjust the private return to home capital to also include the cost that is associated with the change in market services. Specifically, when home and market services are substitutes, a marginal accumulated unit of home capital will reduce the future demand for market services, and this requires the optimal tax on the return to home capital to be strictly positive. The opposite is true when the two types of services instead are complements.

As in Chamely (1986) and Judd (1985), the optimal steady-state tax rate on industrial capital is zero, so untaxable home production does not change this result. Since basically all empirical estimates of the elasticity of substitution are well above one, the results from the theoretical part imply that services should be taxed at a lower rate than goods, and that the return to home capital should be taxed at a strictly positive rate.

In the second and quantitative part of the paper, the model is calibrated to the U.S. and optimal

\footnotetext{
${ }^{6}$ Related studies include Corlett and Hague (1953), Sandmo (1990), Kleven (2004) and Kleven et al. (2000).

${ }^{7}$ Since the Ramsey planner cannot tax the part of the return that is coming from the home-produced services that home capital produce, the tax has to be levied on the stock of undepreciated home capital. The optimal tax rate on the stock of home capital is positive, but it implies a zero tax rate on the total return to home capital.
} 
tax rates are computed on capital, home capital, labor and services. Moreover, since the model provides good predictions of market and home hours for Europe when furnished with European tax rates, optimal tax rates are also computed for Europe. The results verify that the optimal tax rates on services are substantially lower than tax rates on goods. For the U.S., the optimal service tax is in fact negative, whereas it is around five percentage points lower than the tax rate on goods for Europe.

There are large welfare gains from implementing optimal taxes. In contrast to the findings in Chari et al. (1994), the welfare gains do not rely on a very large initial tax rate on capital. In fact, even under the restriction that the tax rate on industrial capital is not allowed to increase, the welfare gain is 1.63 percent of lifetime consumption for the U.S., and as large as seven percent for Europe. The key assumptions are discussed at the end of the paper.

\section{The model}

\subsection{The representative household}

Consider a representative agent with the following instantaneous utility function:

$$
u\left(c_{t}, s_{t}, l_{t}, k_{n, t}\right)=\log \left(c_{t}^{\eta} s_{t}^{1-\eta}\right)+\varphi_{1} \frac{l_{t}^{1-\mu}}{1-\mu}+\varphi_{k} \log k_{n, t}
$$

where $c_{t}$ is consumption goods, $s_{t}$ services, $l_{t}$ leisure and $k_{n, t}$ is home capital, which can be thought of as housing and consumer durables. For simplicity, the utility function is assumed to be additively 
separable in home capital. ${ }^{8}$ Services are an aggregate of market-produced services $s_{m, t}$, and homeproduced (non-market) services $s_{n, t}$ :

$$
s_{t}=\left[\theta\left(s_{m, t}\right)^{\frac{\varepsilon-1}{\varepsilon}}+(1-\theta)\left(s_{n, t}\right)^{\frac{\varepsilon-1}{\varepsilon}}\right]^{\frac{\varepsilon}{\varepsilon-1}} .
$$

The production function for services is a Cobb-Douglas function in home capital $k_{n}$, and hours worked in home production (in efficiency units) $z_{n} h_{n}$, where $z_{n}$ is the constant productivity in home production. The amount of home-produced services $s_{n}$, is thus given by

$$
s_{n} \equiv f^{S}\left(k_{n}, z_{n} h_{t, n}\right)=k_{n}^{\alpha}\left(z_{n} h_{n}\right)^{1-\alpha} .
$$

Home capital depreciates at the rate $\delta_{n}$ between any two consecutive periods. The agent supplies labor to the labor market, consisting of the goods market and the service sector, and she has one unit of productive time per week, which must be divided between market work, home production and leisure

$$
h_{m, t}+h_{n, t}+l_{t}=1
$$

Denoting taxes on consumption, services, labor, home capital and the return to industrial capital

\footnotetext{
${ }^{8}$ The advantage of having home capital be additively separable is that it significantly reduces the number of cross derivatives and therefore simplifies the analysis. A common assumption in the literature on housing is to assume that utility is Cobb-Douglas in consumption and housing (as in Cocco, 2005). Which of these formulations might be more realistic is an empirical question.
} 
respectively by $\tau^{c}, \tau^{s}, \tau^{h}, \tau^{k_{n}}$, and $\tau^{k_{m}}$, the agent's consolidated budget constraint is

$$
\begin{gathered}
\sum_{t=0}^{\infty} q_{t}\left[c_{t}\left(1+\tau^{c}\right)+\left(1+\tau_{t}^{s}\right) p_{t} s_{m, t}+a_{t+1}+k_{n, t+1}\right]= \\
\sum_{t=0}^{\infty} q_{t}\left[w_{t}\left(1-\tau_{t}^{h}\right) h_{m, t}+R_{t} a_{t}+\left(1-\tau_{t}^{k_{n}}\right)\left(1-\delta_{n}\right) k_{n, t}+\Psi_{t}\right],
\end{gathered}
$$

where $\beta$ denotes the subjective discount factor, $q_{t}$ is the price of consumption in period $t, w$ the wage rate, $a$ assets, $p$ the market price of services, $R_{t}=1+\left(1-\tau_{t}^{k}\right)\left[r_{t}-\delta\right]$ the gross aftertax interest rate and $\delta$ is the depreciation rate on industrial capital. $\Psi$ is a transfer from the government that contains the tax revenues which are given back to the consumer, assuming that this part of government consumption is a perfect substitute for privet consumption. Consumption goods, market and home capital all have a relative price of one.

Note that only a part of the return to home capital can be taxed. Specifically, the tax on home capital is levied on the stock of undepreciated home capital, whereas the home-produced services that home capital generate are not explicitly taxed. Note also that $\tau^{c}$ does not depend on time. In the Ramsey problem below, $\tau^{c}$ is held fixed at the initial level throughout the analysis because there is a continuum of tax rates that can implement the optimal allocation if taxes on consumption, labor and capital are all used.

In the model, capital of one type can in each period be converted into the other type, without any frictions or time lags. This is not necessarily realistic and it matters for the transition and for the size of the welfare effects, but it does not matter for the properties of the Ramsey steady state. The case without frictions is a natural starting point, but it is straightforward to introduce 
frictions into the model. ${ }^{9}$

\section{$2.2 \quad$ Firms}

The production side of the economy consists of goods and services. There is no aggregate uncertainty in the economy. Firms rent capital and labor from the representative household. Consumption goods and market services are both produced by combining capital and labor in a Cobb-Douglas technology:

$$
F^{i}\left(k_{i}, h_{i}\right)=k_{i}^{\alpha} h_{i}^{1-\alpha}, \quad i=\{g, s\}
$$

where $k_{j}$ and $h_{j}$, respectively, denote the amounts of capital and labor used in sector $i$. Identical production functions imply that capital's share of income is the same in the production of goods and services, which seems to be empirically true. In fact, Uppenberg and Strauss (2010) show that on average, services have as much fixed capital per employee as manufacturing. ${ }^{10}$

\subsection{The government}

The government sets tax rates to finance the exogenous sequence of constant government consumption $g$. The period- $t$ government budget constraint is given by

\footnotetext{
${ }^{9}$ In addition, on the individual level, investments in housing may be lumpy. Since the model captures the aggregate level and home capital consists of housing and durables, it is feasible to abstract from this type of lumpiness.

${ }^{10}$ The difference is that the service capital stock is more skewed towards buildings as well as information and communication technology.
} 
(7)

$$
g+\Psi_{t}=d_{t}\left(1-R_{t}\right)+\tau^{c} c_{t}+\tau_{t}^{s} p_{t} s_{m, t}+\tau_{t}^{h} w_{t} h_{m, t}+\tau_{t}^{k_{m}} r_{t} k_{m, t}+\tau_{t}^{k_{n}}\left(1-\delta_{n}\right) k_{n, t},
$$

where $d$ is the level of government debt and $k_{m}$ industrial capital.

\subsection{The competitive equilibrium}

The utility-maximization problem for the representative agent is to maximize (1) subject to (5).

Defining the marginal disutility of work as $u_{h_{m, t}} \equiv-u_{l_{t}}$, the first-order conditions with respect to $c_{t}, h_{m, t}, s_{m, t}, h_{n, t}, a_{t+1}$ and $k_{n, t+1}$ are respectively, given by

$$
\beta^{t} u_{c t}-\lambda q_{t}\left(1+\tau^{c}\right)=0
$$

(9)

$$
w_{t}\left(1-\tau_{t}^{h}\right)=-\frac{u_{h_{m, t}}}{u_{c_{t}}}\left(1+\tau^{c}\right)
$$

$$
p_{t}\left(1+\tau_{t}^{s}\right)=\frac{u_{s_{m, t}}}{u_{c_{t}}}\left(1+\tau^{c}\right)
$$

$$
W_{t} \equiv u_{h_{n, t}}+u_{h_{m, t}}=0
$$




$$
-u_{c_{t}}+\beta u_{c_{t+1}} R_{t+1}=0
$$

and

$$
-\frac{u_{c_{t}}}{1+\tau^{c}}+\beta\left(u_{k_{n, t+1}}+u_{c_{t+1}} \frac{\left(1-\tau_{t+1}^{k_{n}}\right)\left(1-\delta_{n}\right)}{1+\tau^{c}}\right)=0 .
$$

Total market hours are divided between the goods and the service sectors, i.e., $h_{m, t}=h_{g, t}+h_{s, t}$. A similar condition must hold for market capital, i.e., in equilibrium it must be true that $k_{m, t}=$ $k_{g, t}+k_{s, t}$. In addition, market clearing in the asset markets requires:

$$
k_{m, t}=a_{t}-d_{t} \quad \forall t .
$$

Competitive pricing ensures that, in each period, the returns to capital and labor in sector $i$ are respectively given by:

$$
r_{i, t}=F_{k_{i, t}}^{i}\left(k_{i, t}, h_{i, t}\right)-\delta, \quad \text { and } \quad w_{i, t}=F_{h_{i, t}}^{i}\left(k_{i, t}, h_{i, t}\right), \quad i=\{g, s\}
$$

For employment to be positive in both sectors, wages have to be the same, i.e.,

$$
w_{t} \equiv w_{s, t}=w_{g, t}, \quad \forall t .
$$


Similary, for investments to be positive in both sectors, the return has to be the same in both sectors, i.e., we must have $r \equiv r_{g}=r_{s}$. This implies that

$$
h_{s, t}=h_{g, t} k_{s, t} / k_{g, t}, \quad \forall t
$$

The price of market-produced services in each period is given by $p_{t} \equiv F_{h_{g}, t}^{g} / F_{h_{s}, t}^{s}=1$. Intuitively, with identical production functions for goods and services, the price of services is equal to one. The aggregate resource constraint in the economy is:

$$
c_{t}+k_{m, t+1}+k_{n, t+1}+g_{t}=F^{g}\left(k_{g, t}, h_{g, t}\right)+(1-\delta) k_{m, t}+\left(1-\delta_{n}\right) k_{n, t} .
$$

Finally, in equilibrium, the demand for market services has to equal the supply of market services. The market-clearing condition for services is given by

$$
s_{m, t}=F^{s}\left(k_{s, t}, h_{s, t}\right) .
$$

\subsection{The Ramsey equilibrium}

The objective of the social planner is to find a sequence of tax rates that fulfills the budget constraint and a transversality condition. This analysis follows Ramsey (1927), who considered the problem of choosing an optimal tax structure in an economy with a representative agent when only distortionary taxes are available. As is standard in this literature, I assume that the planner 
has access to a commitment technology, so that time-inconsistency problems can be ignored. The level of government consumption $g$ and the level of transfers $\Psi$ are both held fixed throughout the transition. Relaxing the restriction that transfers are constant makes it possible for the planner to reduce taxes, which leads to higher welfare gains. In all of the cases below, it is assumed that capital taxes on market and home capital in the first period cannot be changed. This assumption is standard and it is used to rule out lump-sum taxation.

I make use of the primal approach to find the optimal policy. This implies choosing paths for capital stocks, consumption, hours in the goods market, in the service sector as well as in home production, subject to the constraint that these sequences are consistent with household optimization. The principal idea is to use the first-order conditions to define prices, given an allocation. Prices and tax rates can then be substituted away and need not be explicitly included in the planner's problem. Equation (8) defines $q_{t}$, (9) determines $\tau_{t}^{h},(10)$ can be used to compute $\tau_{t}^{s}$, and (12) to set $\tau_{t}^{k_{m}} \cdot{ }^{11}$ Since (11) does not contain any taxes that the government can set directly, this constraint has to be included in the planner's problem. Substituting (9), (10) and (12)-(13) into the household's present-value constraint (5) gives

$$
\begin{gathered}
\sum_{t=0}^{\infty} \beta^{t}\left[u_{c_{t}}\left(c_{t}-\frac{\Psi}{1+\tau^{c}}\right)+u_{s_{m, t}} s_{m, t}+u_{h_{t}} h_{m, t}+\beta\left(u_{s_{n, t+1},} f_{k_{n}, t+1}^{S} k_{n, t+1}+\varphi_{2}\right)\right] \\
-V_{0}=0,
\end{gathered}
$$

where $V^{0}=u_{c_{0}}\left[\left(1+\left(1-\tau_{0}^{k}\right)\left(F_{k_{m}, 0}-\delta\right)\right)\left(k_{m, 0}+d_{0}\right)+\left(1-\tau_{0}^{k_{n}}\right)\left(1-\delta_{n}\right) k_{n, 0}\right]$.

Equation (20) is generally referred to as the implementability constraint, since it is a constraint

\footnotetext{
${ }^{11} q_{0}$ is normalized to unity.
} 
on the set of allocations that can be implemented as a competitive equilibrium with distorting taxes. Let $\Phi$ be a Lagrange multiplier on (20) and define

$$
\begin{gathered}
V=u\left(c_{t}, s_{t}, 1-h_{m, t}-h_{n, t}, k_{n, t}\right)+ \\
\Phi\left[u_{c_{t}}\left(c_{t}-\frac{\Psi}{1+\tau^{c}}\right)+u_{s_{m, t}} s_{m, t}+u_{h_{t}} h_{m, t}+\beta\left(u_{s_{n, t+1},} f_{k_{n}}^{S} k_{n, t+1}+\varphi_{2}\right)\right] .
\end{gathered}
$$

To formulate the planning problem, we can also substitute away $s_{m}$ and $s_{n}$ and instead directly use production functions (3) and (6). Taking (17) into account, services in period $t$ can be written as

$$
s_{t} \equiv \widetilde{s}\left(k_{s, t}, h_{g, t}, k_{g, t}, k_{n}, h_{t, n}\right)=\left[a\left(F^{s}\left(k_{s, t},\left(h_{g, t} k_{s, t}\right) / k_{g, t}\right)\right)^{\frac{\varepsilon-1}{\varepsilon}}+(1-a)\left(f^{S}\left(k_{n}, z_{n} h_{t, n}\right)\right)^{\frac{\varepsilon-1}{\varepsilon}}\right]^{\frac{\varepsilon}{\varepsilon-1}} .
$$

The Ramsey problem can then be formulated as

$$
\begin{aligned}
\max _{\left\{c_{t}, k_{g, t+1}, k_{s, t+1}, k_{n, t+1}, h_{g, t}, h_{n, t}\right\}_{t=0}^{\infty}} \sum_{t=0}^{\infty}\left\{\beta^{t} V\left(c_{t}, \widetilde{s}\left(k_{s, t}, h_{g, t}, k_{g, t}, k_{n, t}, h_{t, n}\right), 1-h_{m, t}-h_{n, t}, k_{n, t}\right)\right. \\
-\lambda_{t}\left[c_{t}+k_{g, t+1}+k_{s, t+1}+k_{n, t+1}+g_{t}-F^{g}\left(k_{g, t}, h_{g, t}\right)\right. \\
\left.-(1-\delta)\left(k_{g, t}+k_{s, t}\right)-\left(1-\delta_{n}\right) k_{n, t}\right]-\chi_{t} W_{t}-\Phi V^{0} .
\end{aligned}
$$

The equations that characterize the Ramsey equilibrium are the optimality condition for home production (11), the requirement for capital returns (17), the resource constraint (18), the marketclearing condition for services (19), the household's present-value constraint (20) and the first-order conditions to $(22) \cdot{ }^{12}$

\footnotetext{
${ }^{12}$ The first-order conditions to the problem in (22) are shown in Appendix A.1.
} 


\section{Optimal Tax Formulas}

By combining the first order conditions to the problem in (22) and allowing $\Psi=0$, it is possible to derive the following optimal tax formulas for $t>1$ :

$$
\tau_{t}^{k_{m}}=0
$$

$$
1+\tau_{t}^{s}=\frac{1+\tau^{c}}{1+\frac{\varepsilon-1}{\varepsilon} u_{l, t} h_{n, t} \bar{\Phi}}
$$

$$
\tau_{t}^{k_{n}}=\left(\frac{R_{t}}{1-\delta_{n}}-1\right) \tau^{c}+\frac{\varepsilon-1}{\varepsilon} \frac{u_{k_{n, t}} u_{s_{m, t}} s_{m, t}}{u_{c_{t}}} \bar{\Phi}(1-\alpha) \frac{1+\tau^{c}}{1-\delta_{n}}
$$

where $\bar{\Phi}$ is the "adjusted" multiplier on the life-time budget constraint. ${ }^{13,14}$ As in Chamley (1986) and Judd (1985), the optimal tax rate on industrial capital is zero, so there is not anything new interesting to say about this tax rate. Turning instead to the service tax, equation (24) says that the optimal tax rate on services should equal the tax rate on consumption goods when $\varepsilon=1$, i.e., when the aggregator function (2) is Cobb-Douglas. In this case, preferences are weakly separable between all traded commodities and labor. This is sufficient for the A-S theorem to apply

\footnotetext{
${ }^{13} \bar{\Phi}$ is defined and explained in Appendix A.1. Setting $\Psi=0$ implies that transfers are zero in the Ramsey equilibrium, which significantly simplifies the algebra.

${ }^{14}$ The optimal tax rates in period $t=1$ only differ from those in (23)-(25) in that (23) and (25) then both contain an extra term that captures the usual spike in the tax rate for capital in the first period of the transition.
} 
and, consequently, commodity taxes should be uniform across goods and services. Note, however, from the agent's first order condition for home hours (11), that the demand for home production is directly linked to the amount of labor supplied. The reason for why the A-S theorem still holds is that the marginal rate of substitution between goods and market services does not depend on home production. The tax rate on market services should therefore not be used to influence home hours.

This is no longer true for values of $\varepsilon$ that are different from one. The marginal rate of substitution between market-produced services and consumption goods then depends on the amount of home hours supplied, and home hours depend directly on the amount of labor supplied. Hence, nonseparability between home and market services, in combination with the fact that home services require time as an input together imply non-separability between traded commodities and labor. The A-S theorem does then not apply and the optimal tax rate on market services should instead internalize the interdependency between home and market services.

The term $u_{l, 1} h_{n, 1}$ in the denominator of (24) is a measure of the net labor income that is lost from working at home rather than in the market (times the marginal utility of consumption). ${ }^{15}$ Each unit of extra income relaxes the life-time budget constraint so the total value of those home hours is $u_{l, 1} h_{n, 1} \bar{\Phi}>0$. The optimal tax on services should thus be lower than the tax on goods when home and market services are substitutes $(\varepsilon>1)$ and vice versa.

Intuitively, the first best requires uniform taxation of all commodities, including leisure and home production. Since all traded goods and services are equally substitutable for leisure, it is not possible to use non-uniform taxation to tax leisure. However, when home and market services are

\footnotetext{
${ }^{15}$ It follows from (9), that the marginal utility of leisure is equal to the net labor income times the marginal utility of consumption.
} 
substitutes a reduction in the tax rate on market services is equivalent to a tax on home production, since it increases the relative price of home production. When the two types of services are instead complements, a tax on market services is equivalent to a tax on home production because the two types of services are then consumed together. ${ }^{16}$

The logic is similar for $\tau^{k_{n}}$, but (25) is somewhat more involved, partly because only a part of the return to home capital can be taxed. The first term in (25) neutralizes the distortion generated by $\tau^{c}$ in the investment decision for home capital. Too see this, note from the agent's first-order condition (13), that the return to home capital consists of two parts. First, the agent derives utility from the home-produced services that home capital produce. Second, she can also derive utility from consuming what is left of the investment after depreciation and the tax on home capital has been paid. Because home production is untaxed whereas goods are taxed at rate $\tau^{c}$, the consumption tax drives a wedge between one part of the return, as well as the cost of the investment on the one hand, and the home-produced part on the other hand. Substituting (25) into the agent's first order condition for home capital (13) delivers

$$
\frac{u_{k_{n, t}}}{u_{c_{t}}}+\left(1-\delta_{n}\right)-\frac{\varepsilon-1}{\varepsilon} u_{k_{n, t}} \frac{u_{s_{m, t}} s_{m, t}}{u_{c_{t}}} \bar{\Phi}(1-\alpha)=R_{t}
$$

When $\varepsilon=1$, the third term on the left hand side of $(26)$ is zero, thus implying that the private

\footnotetext{
${ }^{16}$ These results are consistent with several previous studies. Corlett and Hague (1953) first, consider a setting without home production and show that the optimal tax system implies relatively high taxes on commodities that are complementary to leisure. Second Kleven (2004) analyzes optimal taxes in a setting where agents combine market goods and time in a Leontief production function to derive utility. The optimal tax system then features relatively low taxes on market goods that requires little household time. Market services save time so they should therefore have a low or negative tax rate. The conclusion is thus the same as in this paper, but the argument is different. Third, Kleven et al. (2000), consider a model that is similar to the one in this paper. They abstract from (both home and industrial) capital and assume home and market services to be perfect substitutes and they show that market services should carry a lower tax rate than goods. See also Sandmo (1990).
} 
return to home capital $\left(u_{k_{n, t}} / u_{c_{1}}+1-\delta_{n}\right)$ is equal to the return to industrial capital $\left(R_{t}\right)$. Since industrial capital is untaxed according to (23), equation (26) is identical to the first order condition that would result in an economy without any taxes. The positive optimal tax rate on the stock of home capital thus effectively implies a zero tax rate on the total return to home capital. ${ }^{17}$

When, $\varepsilon \neq 1$, however, the level of home production enters directly into the agent's first order condition for market services (10), again implying that preferences no longer are weakly separable between the traded commodities and labor. In fact, when home and market services are substitutes, a marginal unit of accumulated home capital will reduce the demand for market services in the subsequent period, and this reduction constitutes a cost. The second term in (25) internalizes this effect. Note from (10) that $u_{s, m, 1} s_{m, 1} / u_{c, 1}$ is the total amount of resources spent on market services and, as explained above, $\bar{\Phi}$ is a measure of the value of these services. The size of the drop in market services is proportional to $u_{k_{n}}(\varepsilon-1) / \varepsilon$, i.e., it is increasing in both the marginal utility of home capital and the elasticity of substitution. A substitution-elasticity larger than one thus requires a higher tax rate on home capital to make the private after-tax return equal to the social return (which is the private return before taxes, minus the value of lost market services). In contrast, when the two types of services are complements, more home capital increases the demand for market services and this is beneficial. In this case, home capital should be subsidized. Since basically all empirical estimates of the elasticity of substitution are well above one, however, the tax rate on services should be lower than the tax rate on goods, and the tax rate on the return to home capital should be strictly positive.

In addition, parameters and policies that increase $h_{n}$ and $u_{l}$ tend to strengthen the argument

\footnotetext{
${ }^{17}$ Put differently, when $\varepsilon=1$ the A-S theorem holds and optimality then requires uniform taxtation of consumption at different points in time, which can only be acheived with zero tax rates on capital returns.
} 
for a reduced tax on market services, whereas parameters and policies that increase $u_{k_{n}}$ and the demand for market services strengthen the argument for a higher tax on home capital. As will be shown in section 6 , this logic is correct.

Finally, nothing has been said about the labor tax, but this tax rate is basically a residual that has to be set to the value that exactly balances the government's budget constraint.

\section{Calibration}

Let us now calibrate the model to match the U.S. In addition, since the model successfully predicts European market and home hours when furnished with European policy instruments, optimal tax rates on capital, home capital, labor and services are computed for both the U.S. and Europe. European values for policy and hours are computed as averages of values in Belgium, Denmark, France, Germany, Italy, the Netherlands, Sweden and the U.K.

One period is assumed to be one year. The preference parameters are $\beta, \mu, \eta, \varphi_{1}, \varphi_{2}, \theta$ and $\varepsilon$. The parameter $\beta$ is set to 0.96 in order to generate a steady-state interest rate around four percent. The parameter $\mu$ is set to 5 , which implies that the intertemporal (Frisch) elasticity of substitution for labor is $0.50 .^{18}$

The parameter $\eta$ in the utility function is set to 0.20 , so that roughly fifty percent of private consumption comes from services as in the U.S. ${ }^{19}$ The weight parameter on leisure, $\varphi_{1}$, is chosen to match the fact that Americans work 26.50 hours per week on average, which implies $\varphi_{1}=0.151 .^{20}$

\footnotetext{
${ }^{18}$ The Frisch elasticity of labor supply is defined as the elasticity of labor supply with respect to the wage, keeping the marginal utility of consumption constant. In the model, this elasticity is given by $\frac{l_{i t}}{h_{i}} \frac{1}{\mu}$. Estimates of the Frisch elasticity in models without home production are found in the interval 0-0.3 for men, with most of them in the lower range of this interval. See Browning et al. (1999) for a survey. Estimates for women are generally higher.

${ }^{19}$ The average share of market services in GDP is around 50 percent in the raw data for the period 1980-2007 (EU KLEMS, 2009).

${ }^{20}$ To compute hours worked per person, total hours worked are first divided by the number of persons aged 15-64.
} 
The weight on market services $a$, is set to 0.3595 to match the fact that Americans devote 39 percent of their total working time to home production.

A key parameter governing a household's choice between market-produced and home-produced services is the elasticity of substitution between these goods, i.e., $\varepsilon$. Estimates of the elasticity $\varepsilon$ are found to have a wide range in the literature. McGrattan, Rogerson and Wright (1997) use aggregate time series for a business-cycle model with home production to assess the elasticity. They find an elasticity in the range 1.7-1.8. Using micro data that include information on time spent in home production, Rupert, Rogerson and Wright (1995) find similar values. Chang and Schorfheide (2003) find higher values: 2.2-2.5. These values all correspond to the elasticity of substitution between all market and non-market consumption, whereas the model refers to the elasticity between market and non-market services. For this reason, Ragan (2005) calibrates the elasticity to be 10. Against this background, $\varepsilon$ is set to 2.5 in the benchmark calibration, but a lower value is considered in the sensitivity analysis.

The parameter $\varphi_{k}$ is the weight on home capital in the utility function. Home capital is defined as an aggregate of durable consumption goods and residential housing. Feldstein (1980) shows that the ratio of the residential stock relative to the total capital stock is 0.48 in the U.S. Unfortunately, I have not been able to find good estimates on the stock of consumer durables. However, since most durable goods have a short life span relative to houses, in combination with the fact that the estimate of the total capital stock includes consumer durables during the period analyzed by Feldstein, I set $\varphi_{k}=0.36$, which implies that market capital constitutes roughly 50 percent of the

This number is then divided by 5200 (52 weeks times 100 productive hours per week), and then multiplied by 100 to obtain the percentage terms. In this way, the numbers express both hours in percent and hours per week. Data on total hours worked are taken from EU KLEMS (2009) and data on the population aged 15-64 are taken from the OECD database on Employment and Labor Market Statistics. 
total capital. In the sensitivity analysis, an alternative value is considered.

Turning now to production parameters, Bridgman (2013) estimates that productivity in home production in the U.S. has been between $0.4-0.6$ of the productivity in market work since 2000 . Based on this estimate, $z_{n}$ is set to 0.55 , thus implying that home productivity is roughly half the value of market productivity (which is normalized to one). This value is also varied in the sensitivity analysis. Parameter $\alpha$ governs capital's share of income and is set to its standard value of 0.30 . The depreciation rate for home capital is set to 0.2, which is based on the estimate in Baxter (1996). Specifically, she defines the bundle of durable consumption goods as an aggregate which includes the National Income and Product Accounts (NIPA) definition (motor vehicles, furniture, stereos, televisions, boats, jewelry and books ), combined with the stock of residential housing. Using an annual depreciation for the NIPA goods of $22 \%$ and an annual rate just below $4 \%$ for housing, Baxter computes the weighted average depreciation rate for aggregate consumption durables to be about $0.16 .^{21}$ Since then, however, a number of goods with much higher depreciation rates (such as computers, software, cell phones, electronic tablets etc.) have become increasingly more important. ${ }^{22}$ For this reason, I set the depreciation rate for durable goods to be slightly higher than the estimate by Baxter.

The depreciation rate for productive capital is set to 0.12 . This is also slightly higher than the standard value (around 0.08), and it is needed to prevent the ratio of the residential stock relative to the total capital from becoming too high. As in almost all macroeconomic models, however, the level of the depreciation rate is quantitatively unimportant for the results. ${ }^{23}$

\footnotetext{
${ }^{21}$ The weight on residential housing is 0.35 .

${ }^{22}$ According to the U.S. Bureau of Economic Analysis (BEA), the depreciation rate for computers, for example, is about 0.55 .

${ }^{23}$ Welfare effects are, in fact, slightly higher when the depreciation rate is low because the spike in first-period consumption in the transition is then larger. Quantitatively, however, this is effect is small.
} 
Data on initial debt are taken from the National Accounts and set to 0.80 for Europe and 0.65 for the U.S. ${ }^{24}$ Government consumption and the level of transfers are both required to be constant in the transitions. Using data from the National Accounts, government consumption is set to 22 percent of GDP and the transfer $\Psi$ is then residually determined from the governments budget constraint.

Average effective tax rates (AETRs) on labor, consumption, services and industrial capital for Europe and the U.S. are estimated from National Accounts data and Revenue Statistics. Due to a lack of data, however, the tax rates on home capital are calibrated instead of estimated. Since home capital is defined as a bundle that consists of durable goods and the stock of residential housing, $\tau^{k_{n}}$ is a weighted average of the tax on durables and the property tax. Tax rates on property are estimated in OECD (2014), durable goods are assumed to be taxed at the rate $\tau^{c}$ and the weight on residential housing is 35 percent (as in Baxter, 1996). ${ }^{25}$ Details about the estimation procedure are found in Appendix A.3 and the estimated tax rates are shown in Table 1.

Table 1: AETRs in percent in Europe and the U.S.

\begin{tabular}{ccccc|ccccc}
\hline \hline$\tau_{E U}^{s}$ & $\tau_{E U}^{c}$ & $\tau_{E U}^{h}$ & $\tau_{E U}^{k_{m}}$ & $\tau_{E U}^{k_{n}}$ & $\tau_{U S}^{s}$ & $\tau_{U S}^{c}$ & $\tau_{U S}^{h}$ & $\tau_{U S}^{k_{m}}$ & $\tau_{U S}^{k_{n}}$ \\
\hline 17.00 & 17.00 & 40.00 & 25.00 & 3.53 & 0.00 & 8.00 & 26.79 & 28.00 & 1.79 \\
\hline
\end{tabular}

$\tau^{s}$ - the value added tax on market services, $\tau^{c}$ - the value added tax on consumption goods, $\tau^{h}$ - the tax on labor income, $\tau^{k_{m}}$ - the tax on the return to industrial capital and $\tau^{k_{n}}$ - the tax on undepreciated home capital.

Market hours are computed from the EU KLEMS database (2009) and from the OECD database on Employment and Labor Market Statistics (see footnote 19). The estimate for time spent in home production in the U.S. is 17.15 hours per person and week, which is taken from Olovsson (2009). Ragan (2005) shows that the amount of time spent in home production in Europe is 8-16 percent

\footnotetext{
${ }^{24}$ Values for 2010 .

${ }^{25}$ Note that the tax on home capital has to be paid in every period that undepreciated home capital remains. The NPV of the steady-state tax rate on one unit of home capital is 6 and 12 percent for the U.S. and Europe respectively.
} 
higher than in the U.S. ${ }^{26}$ Since Europe in this study is an average across several countries, I consider European home hours to be 13 percent higher than in the U.S., which is close to the mean of the interval. ${ }^{27}$ Data and model predictions on market and home hours in steady states are shown in Table 2 .

Table 2: Hours worked per person in the data and the model

\begin{tabular}{lcccc}
\hline \hline & \multicolumn{2}{c}{ Data } & \multicolumn{2}{c}{ Model } \\
& U.S. & Europe & U.S. & Europe \\
\hline Market work & 26.50 & 22.00 & 26.50 & 22.23 \\
Home production & 17.15 & 19.40 & 17.15 & 20.27
\end{tabular}

Assuming 100 productive hours per week, the numbers both express hours per week and hours expressed in percent of total productive time. Source for market hours: EU KLEMS, November 2009. The estimates for home production are based on Ragan (2005) and Olovsson (2009).

\section{Results}

The results for the benchmark calibration are reported in this section. Results with alternative calibrations are reported in Section 6 .

\subsection{Optimal taxation}

Actual and optimal tax rates for the U.S. and Europe are displayed in Table 3.

The main intuition behind these tax rates has already been provided in Section 3. The optimal steady-state tax rate on capital is zero as shown in (23). The optimal tax rate on services is close to zero for the U.S. and it is significantly lower than the tax rate on goods for Europe. The optimal tax rates on home capital are higher than current tax rates. Labor taxes are significantly lower in the

\footnotetext{
${ }^{26}$ Home hours in Italy and the Netherlands are missing from the data.

${ }^{27}$ The estimate for hours spent in home production in Sweden is significantly lower in Ragan (2005) than in Olovsson (2009). In the former study, there is no difference between Sweden and the U.S., whereas in the latter study home hours are 11 percent higher in Sweden than in the U.S. Time-use surveys are generally hard to compare, but Olovsson made use of a time-use survey that is claimed to be comparable for Sweden and the U.S. For this reason, European home hours are set to a value slightly higher than the mean of the interval.
} 
Table 3: Actual and optimal steady-state tax rates in percent

\begin{tabular}{lcccc|c}
\hline \hline & $\tau^{k_{m}}$ & $\tau^{k_{n}}$ & $\tau^{h}$ & $\tau^{s}$ & $\tau^{c}$ \\
\hline AETRs in the U.S. & 28.00 & 1.79 & 26.79 & 0.00 & 8.00 \\
Optimal steady-state tax rates for the U.S. & 0.00 & 3.32 & 12.86 & 0.60 & 8.00 \\
AETRs in Europe & 25.00 & 3.53 & 40.00 & 17.00 & 17.00 \\
Optimal steady-state tax rates for Europe & 0.00 & 9.96 & 7.46 & 12.35 & 17.00 \\
\hline \multicolumn{1}{c}{$\tau^{c}$ is exogenous for the Ramsey planner. }
\end{tabular}

Ramsey equilibrium. Intuitively, with higher tax rates on home capital, more efficient production and with the government holding negative quantities of debt, the labor tax can be reduced. ${ }^{28}$

\subsection{Initial steady states versus Ramsey equilibria}

Initial steady states are compared with steady states in the Ramsey equilibria for the U.S. and Europe, respectively, in Table 4. Figures 1 and 2 in Appendix A.4 plot the full transition. The welfare measure used is the constant percentage amount by which the consumption of goods, services and home capital must be increased in all periods in the benchmark economy, so as to yield the same utility as under the policy experiment.

The results show that except for home hours, all variables are higher in the Ramsey than in the initial allocations. The reduction in home hours leads to a reduction in home production. ${ }^{29}$ For the U.S., market hours are about ten percent higher and home hours are roughly twelve percent lower.

The stock of industrial capital is significantly higher in the Ramsey allocation than in the initial economies. As in the standard model without home production, capital accumulation is stimulated by the zero tax rate on industrial capital. In the model with home production, an additional effect

\footnotetext{
${ }^{28}$ The initial debt level is 80 and 65 percent of GDP, respectively, for Europe and the U.S. In the Ramsey equilibria, the debt levels are around -40 percent of GDP for both regions.

${ }^{29}$ Figure 1 in the Appendix shows that the steady-state level of home production is lower in the Ramsey allocation than in the initial allocation.
} 
Table 4: Initial and optimal steady-state allocations in the U.S. and Europe

\begin{tabular}{lccccccc}
\hline \hline & $c$ & $s_{m}$ & $k_{m}$ & $k_{n}$ & $h_{m}$ & $h_{n}$ & Welfare \\
\hline U.S. - Initial allocation & 4.47 & 3.59 & 56.91 & 55.44 & 26.50 & 17.15 & 0.00 \\
U.S. - Ramsey allocation & 5.19 & 5.02 & 70.33 & 59.44 & 29.09 & 15.28 & 2.50 \\
Europe - Initial allocation & 3.76 & 1.97 & 47.79 & 51.77 & 22.23 & 20.27 & 0.00 \\
Europe - Ramsey allocation & 5.38 & 4.86 & 66.24 & 56.93 & 27.42 & 16.33 & 8.66
\end{tabular}

Steady-state values for consumption, market services, industrial capital, home capital, market hours and home hours.

emanates from the reallocation of labor from the home sector to the market sector. The increase in labor supply also stimulates savings since the interest rate is high when the capital/labor ratio is low.

The stock of home capital is higher in the Ramsey allocation. This might be surprising, since the tax rate on home capital is higher in the Ramsey allocations than in the initial economies. The intuition for this is that the switch to the Ramsey economy creates income and substitution effects. The income effect is due to the removal of distortions. Fewer distortions enable a higher income, and a higher income increases the consumption level of all normal goods. For home capital, the higher tax rate also creates a substitution effect and this has a negative effect on the stock of home capital. The stock of home capital will then increase if the income effect dominates the substitution effect, even though the Ramsey tax rate on home capital is larger than the initial tax rate. ${ }^{30}$

For market services, a lower tax rate in combination with a higher average income contribute to a higher consumption level of market services. The increase in market services is larger for Europe than for the U.S., because the tax rate on services is reduced more in Europe. ${ }^{31}$ The effects are

\footnotetext{
${ }^{30}$ This can be shown analytically for the case $\varepsilon=1$. Specifically, with $\tau^{k_{n}}$ initially equal to zero, the steadystate level of home capital in the Ramsey allocation is given by $k_{n, s s}^{R}=k_{n, s s} c_{s s}^{R} /\left(c_{s s}\left(1+\tau^{c}\right)\right)$, where superscript $R$ denotes variables in the Ramsey allocation and variables without a superscript refer to those in the initial steadystate allocation. It immediately follows that the steady-state level of home capital will increase if the optimal policy increases steady-state consumption relative to the initial level of after-tax consumption (i.e., if there is an income effect). Specifically, $k_{n, s s}$ can be obtained by solving (13) for the stock of home capital, and $k_{n, s s}^{R}$ can be obtained by solving (26) for $k_{n, s s}^{R}$.

${ }^{31}$ The initial tax rate on services is, in fact, close to the optimal value for the U.S.
} 
larger for Europe in general. In particular, labor supply increases by roughly 25 percent and the size of the service sector more than doubles after implementation of the optimal policy. In contrast, home hours decrease by 25 percent. Even though these effects are large, the difference in labor supply is, in fact, smaller than the real-world difference in labor supply between France and the U.S., which is 30 percent.

\subsection{Welfare}

The welfare gains associated with the transitions are large and equal to 2.50 and 8.66 percent, respectively, for the U.S. and Europe. As a comparison, the largest welfare gain found by Chari, Christiano and Kehoe (1994) in a stochastic setting is just above six percent. In a standard model without home production, a large part of the welfare gain is due to the high tax rate on capital in the first period of the transition. ${ }^{32}$ The high initial tax rate forces the agent to consume a large part of her capital to safeguard it from taxation, and this creates a spike in first-period consumption. In contrast, with home production, the high initial tax rates on capital only cause a drop in the stock of home capital, whereas the stock of industrial capital is basically unaffected (as can be seen in Figure 1). As in the standard model however, the reduction in (home) capital also generates a spike in first-period consumption.

The transitional properties of the optimal tax scheme can easily be criticized as lacking realism. In practice, it could be difficult to implement capital tax rates around 1000 percent (see Figure 2 in the Appendix). To analyze the extent to which welfare gains depend on the initial tax rates in the model with home production, capital taxes are now restricted to be below a certain threshold level. Specifically, it is assumed that capital tax rates are not allowed to increase. The following

\footnotetext{
${ }^{32}$ See Chari et al. (1994).
} 
restrictions are thus added to the Ramsey problem as stated in (22):

$$
\tau_{E U, t}^{k_{m}} \leq \tau_{E U}^{k_{m}} \quad \forall t \quad \text { and } \quad \tau_{U S, t}^{k_{m}} \leq \tau_{U S}^{k_{m}} \quad \forall t
$$

where $\tau_{E U}^{k_{m}}$ and $\tau_{U S}^{k_{m}}$ are the initial steady-state tax rates that are reported in Table 1. The welfare effects and the optimal steady-state tax rates associated with this exercise are shown in Table 5, and the full transitions are plotted in Figures 1 and 2 in the Appendix.

Table 5: Optimal steady-state tax rates with restrictions on the capital tax rate

\begin{tabular}{lccccc}
\hline \hline & $\tau^{k_{m}}$ & $\tau^{k_{n}}$ & $\tau^{h}$ & $\tau^{s}$ & Welfare \\
\hline U.S. & 0.00 & 3.88 & 20.74 & -2.67 & 1.63 \\
Europe & 0.00 & 12.14 & 16.15 & 11.81 & 7.39 \\
\hline \multicolumn{5}{c}{ All tax rates are in percent. }
\end{tabular}

The results show that restrictions on capital taxes lead to higher steady-state tax rates on labor and home capital, and to a lower steady state tax rate on services. Even though welfare gains are lower, they are still significant. In particular, Europe would benefit substantially from a tax reform. As can be seen in Figure 1, the spike in first-period consumption disappears when the capital tax is not allowed to increase, and this is what reduces the welfare effects. Capital is instead reallocated from the home sector to the goods sector in the first period of the transition.

Note finally, that with restrictions $\tau^{k_{m}}$, there is still a peak in $\tau^{k_{n}}$ in the first period of the transition. However, the peak in the home capital tax is several orders of magnitude smaller than the usual peak in the tax rate on industrial capital. 


\section{Sensitivity analysis}

Section 3 identifies the crucial determinants for the optimal tax rates on market services and home capital. In this section, alternative values for three potentially important parameters are considered to evaluate the quantitative effects on tax rates and welfare effects. Specifically, the parameters considered are $z_{n}, \varphi_{k}$ and $\varepsilon$.

In the benchmark calibration, the representative agent's labor productivity in home production is roughly equal to half of her labor productivity in market work. Here, the labor productivities in these two activities are assumed to be the same. The benchmark calibration of the taste parameter for home capital involves matching the ratio of market capital to the total capital stock. In this section, the extreme value of $\varphi_{k}=0$ is considered. This means that the agent does not receive any direct utility from holding home capital. The elasticity of substitution between market and home services is set to a more conservative estimate of 1.8. Optimal U.S. steady-state tax rates and welfare effects for all three cases are displayed in Table $6 .{ }^{33}$

Table 6: Optimal steady-state tax rates and welfare effects with different parameter values

\begin{tabular}{ccccc}
\hline \hline & $\tau_{U S}^{k_{n}}$ & $\tau_{U S}^{s}$ & $\tau_{U S}^{h}$ & Welfare \\
\hline$z_{n}=1$ & 3.24 & 0.37 & 12.39 & 2.67 \\
$\varphi_{k}=0$ & 4.77 & -0.94 & 17.40 & 2.76 \\
$\varepsilon=1.8$ & 3.21 & 3.12 & 13.30 & 2.23
\end{tabular}

All tax rates are in percent and each row reports the tax rates and welfare effects associated with the change of one parameter.

To understand the tax rates in Table 6 , recall from equation (24), that a parameter influences the optimal tax rate on services at time $t$, if it influences the marginal utility of leisure and/or the number of home hours in that period (and/or $\bar{\Phi})$. Similarly, according to $(25)$ a parameter affects

\footnotetext{
${ }^{33}$ Each rows report the tax rates and welfare effects associated with the change of one parameter. This implies that the initial economy no longer exactly matches all calibration targets for the U.S. Steady-state taxes on industrial capital are not reported because they are zero in all the considered cases.
} 
the optimal tax rate on home capital at time $t$, if it influences the marginal utility of home capital and/or the demand for market services at time $t$ (and/or $\bar{\Phi}$ ).

Hours and consumption levels are not reported in the table, but a higher $z_{n}$ is associated with higher levels of both home hours and home capital and since $\varepsilon>1$, more home produced services implies a lower demand for market services. More home capital is associated with $u_{k_{n}}$ so all else equal, an increase in $z_{n}$ requires lower tax rates on both services and home capital relative to in the benchmark calibration.

A lower taste for home capital makes the agent holds less home capital and work more home hours. Overall, the amount of home services produced is lower than in the benchmark calibration and the demand for market services is higher. A lower value for $\varphi_{k}$ thus results in a lower tax rate on services and higher tax rate on home capital relative to in the benchmark calibration. A lower elasticity finally, directly implies a higher tax rate on services and a lower tax rate on home capital relative to in the benchmark calibration.

The labor tax rate is residually determined and must be increased (decreased) when the tax revenues from consumption goods, market services and home capital are decreased (increased). The sensitivity analysis shows that the welfare effects are not that sensitive to the considered parameters and that the main results are fairly robust to relatively large changes in the parameters.

\section{Discussion}

As all economic models, the model here is a stylized version of the real world and it incorporates several simplifying assumptions. This discussion focuses on some of the key assumptions and the potential implications of relaxing them. Consider first the fact that the utility function in the 
model features a constant elasticity of substitution (CES) between home and market services. This assumption is standard in the macroeconomic literature, but a relevant question is how the results would change with a non-constant elasticity of substitution (as often assumed in the theoretical literature).${ }^{34}$ The preceding analysis shows that this elasticity determines the extent to which the planner can use other tax rates to influence the relative price of home production. This should be true independent of whether the elasticity is constant or not. Hence, even though overall effects could be smaller with a decreasing elasticity of substitution (because the agent then values market services less and less), a decreasing elasticity is unlikely to overturn the result of a lower tax rate on services. The properties of the elasticity of substitution are important, however, for the exact values of the optimal tax rates and the welfare effects.

One way to achieve a connection between the micro and the macro literature would be to make home capital a lumpy investment. Small reform changes would then only produce small changes in home hours, because the stock of home capital is left unaffected. The implication is a decreasing elasticity of substitution between home and market services for small reforms. Large reforms, however, also generate investments in home capital and therefore also lead to a larger response in home hours. Lumpy home capital is a realistic assumption, but it mainly affects the transition and the size of the welfare effects, and not the optimal steady-state tax rates. ${ }^{35}$

Second, the results above suggest that technical progress is unimportant for the optimal tax rates. ${ }^{36}$ This might be surprising in terms of the findings in Greenwood, Seshadri and Yorokuglu (2005) whereby technological progress in the home sector is important for explaining the reduction

\footnotetext{
${ }^{34}$ See for instance Ermisch (2003).

${ }^{35}$ Greenwood, Seshadri and Yorukogli (2005) find lumpy home capital to be crucial in explaining the observed paths for (home) technology adoption and diffusion.

${ }^{36}$ Specifically, it was shown in Section 6 that the level of productivity in home production does not matter much for the optimal tax rates.
} 
in housework and the increase in market work during the 20th century. Their model differs from the one in this paper in two important respects: (i) they assume the production function for home services to be Leontief in hours and capital (whereas it is Cobb-Douglas in this paper); and (ii) they assume that technical change is investment specific (whereas it is Hicks neutral here). These specific assumptions are important for the results. If the substitution elasticity between capital and hours is higher than one, the tax rate on home capital is potentially a more efficient instrument for reducing home hours. Similarly, if technical change in home production is embodied in home capital, the planner might want to stimulate R\&D in that sector and also encourage its adoption. Future empirical research is necessary to determine what would be a realistic production function for home-produced services and to what extent technical progress in home production is investment specific.

Third, our model abstracts from heterogeneity. The A-S theorem was originally derived in a setting where agents differ with respect to a number of characteristics. A relevant question is therefore whether the main results in this paper would change if heterogeneity were incorporated into the model. However, since heterogeneity does not alter the fact that the planner must adjust other tax rates in order to increase the relative price of home production, it seems likely that also with heterogeneity, the planner will implement lower tax rates on market services and then use differentiated labor tax rates to achieve the desired level of redistribution. ${ }^{37} \mathrm{~A}$ formal analysis of heterogeneity is required, but that has to be left for future research.

Even if heterogeneity would not change the main results, it is possible that the optimal policy could have implications for redistribution. One potential source for redistribution could be changes

\footnotetext{
${ }^{37}$ Introducing heterogeneity would be straightforward since the model in this paper builds on the model in Olovsson (2009), which incorporates heterogeneity.
} 
in relative wages. Specifically, in a setting where low-skilled agents work in the service sector, and high-skilled agents work in the goods sector, the relative wage between the two sectors could be affected. Since the service sector expands more than the goods sector under the optimal policy, the wage rate and the labor supply are both expected to increase relatively more in the service sector. ${ }^{38}$ An increase in the supply of market-produced services is then likely to benefit the low skilled more than the high skilled. ${ }^{39}$ Another concern could emerge from the suspicion that only high-income agents consume market services, and that they may therefore gain more than the poor. Olovsson (2009), however, documents that low-income households also spend a large fraction of their income on market services.

Fourth and finally, the model abstracts from the fact that goods and services may be more or less complimentary to leisure and that this may be important for the optimal tax rates. Based on the results in Kleven (2004), I expect that such an extension will only strengthen the results in this paper. Specifically, he shows that any market good, which requires little household time or saves time, should carry a low tax rate. Since most market services save household time, they should have lower tax rates. A formal analysis of this aspect also has to be left for future research.

\section{Conclusions}

In this paper, optimal tax policy is analyzed in a fully dynamic setting where a representative agent takes decisions on how to allocate her income between consumption goods, market services and savings, and how to allocate her time between market work, home production and leisure.

\footnotetext{
${ }^{38}$ The expansion comes largely from the allocation of more capital to the service sector, which increases labor productivity.

${ }^{39}$ More work in the service sector can be due to longer work weeks. If skill formation is endogenous, it can also arise because more people choose to remain unskilled. This requires that the return to unskilled work (i.e., the wage rate) increases in relative terms.
} 
In the first and theoretical part of the paper, it is shown that the well-known Atkinson-Stiglitz separability theorem, which states that commodity taxes should be uniform across goods and services, is not applicable in general when taking into account that households also produce services in home production. Specifically, the fact that home production requires time as an input makes the necessary assumption that preferences are separable between all commodities and labor break down (unless the elasticity of substitution between home and market services is exactly equal to one). Instead, services should be taxed at a lower rate than goods and the return to home capital should be taxed at a strictly positive rate if home and market services are substitutes, whereas the opposite is true if they are complements. The optimal steady-state tax rate on industrial capital is still zero, so untaxable home production does not change this result.

In the second and quantitative part of the paper, the model is calibrated and optimal tax rates on capital, home capital, labor and services are computed for Europe and the U.S. The results from this exercise show that the optimal tax rates on services are substantially lower than tax rates on goods and that the return to home capital should be taxed at a positive rate. In addition, there are large welfare gains from implementing the optimal taxes and these welfare gains do not rely on a very large initial tax rate on capital.

\section{References}

[1] Atkinson, Anthony B. and Joseph E. Stiglitz (1972). "The Structure of Indirect Taxation and Economic Efficiency". Journal of Public Economics 1, pp. 97-119.

[2] Atkinson, Anthony B. and Joseph E. Stiglitz (1976). "The Design of Tax Structure: Direct Versus Indirect Taxation". Journal of Public Economics 6, pp. 55-75. 
[3] Marianne Baxter (1996). "Are Consumer Durables Important for Business Cyces". The Review of Economics and Statistics 78, No. 1, pp.147-155.

[4] Bridgman, Benjamin (2013). "Home Productivity", BEA working paper 0091, Bureau of Economic Analysis, Washingon, DC.

[5] Browning, Martin, Lars P. Hansen and James J. Heckman (1999). "Micro Data and General Equilibrium Models," in Taylor, John B and Michael Woodford (eds.), Handbook of Macroeconomics, Amsterdam: North-Holland.

[6] Chamley, Christophe (1986). "Optimal Taxation of Capital Income in General Equilibrium with Infinite Lives". Econometrica 54, No. 3, pp. 607-622.

[7] Chang, Yongsung and Frank Schorfheide (2003). "Labor Supply Shifts and Economic Fluctuations". Journal of Monetary Economics 50, pp. 1751-1768.

[8] Chari, Varadarjan V., Lawrence Christiano and Patrick Kehoe (1994). "Optimal Fiscal Policy in a Business Cycle Model". Journal of Political Economy 102, pp. 617-652.

[9] Cocco, João (2005). "Portfolio Choice in the Presence of Housing". The Review of Financial Studies 18, No. 2, pp.535-567.

[10] Corlett, W. J., and D. C. Hague (1953). "Complementarity and the Excess Burden of Taxation". The Review of Economic Studies 21, No. 1, pp. 21-30.

[11] Ermisch, John F. (2003). "An Economic Analysis of the Family". Princeton University Press, Princeton and Oxford.

[12] EU KLEMS Database, 2009. (On-line data). 
[13] Greenwood, Jeremy., Ananth Seshadri and Mehmet Yorukoglu (2005). "Engines of Liberation". Review of Economic Studies 72, pp. 109-133.

[14] Isaacson, George and David Bertoni (2000). "A Tax Whose Time has Passed? Problems With State Sales and Use Taxes in An Electronic Commerce Environment.", Mimeo, Lewiston, MA.

[15] Feldstein, Martin (1980). "The Distribution of the U.S. Capital Stock Between Residential and Industrial Uses". NBER working paper No. 448.

[16] Freeman Richard B. and Ronald Schettkat (2002). "Marketization of Production and the U.S.Europe Employment Gap". NBER working paper No. 8797.

[17] Judd, Kenneth L (1985). "Redistributive Taxation in a Simple Perfect Foresight Model". Journal of Political Economy 28, pp. 59-84.

[18] Kleven, Henrik Jacobsen (2004) "Optimal Taxation and the Allocation of Time". Journal of Public Economics 88, pp. 545-557.

[19] Kleven, Henrik Jacobsen, Wolfram F. Richter and Peter Birch Sorensen (2000). "Optimal Taxation with Household Production". Oxford Economic Papers 52, pp. 584-594.

[20] McGrattan, Ellen, Richard Rogerson, and Randall Wright (1997). "An Equilibrium Model of the Business Cycle with Household Production and Fiscal Policy". International Economic Review 38, pp. 267-290.

[21] Mendoza, Enrique G., Assaf Razin and Linda L. Tesar (1994) "Effective Tax Rates in Macroeconomics: Cross-Country Estimates of Tax Rates on Factor Incomes and Consumption". Journal of Monetary Economics 34, pp. 297-323. 
[22] Ngai, Rachel L. and Christopher Pissarides (2008). "Trends in Labour Supply and Economic Growth". Review of Economic Dynamics 11, pp. 239-256.

[23] OECD Data base on National Accounts.

[24] Olovsson, Conny (2009). "Why Do Europeans Work so Little?". International Economic Review 50, Nr.1, pp. 39-61.

[25] Prescott, Edward C. (2004), "Why Do Americans Work So Much More than Europeans?". Quarterly Review of the Federal Reserve Bank of Minneapolis, pp. 2-13.

[26] Ragan, Kelly (2005). "Fiscal Policy and the Family: Explaining Labor Supply in a Model with Household Production". Mimeo, University of Chicago.

[27] Ramsey, Frank P. (1927). "A Contribution to the Theory of Taxation". Economic Journal 37, pp. $47-61$.

[28] Rogerson, Richard (2008). "Structural Transformation and the Deterioration of European Labor Market Outcomes". Journal of Political Economy 116, No. 2, pp. 235-259.

[29] Rupert, Peter, Richard Rogerson and Randall Wright (1995). "Estimating Substitution Elasticities in Household Production Models". Economic Theory 6, pp. 179-193.

[30] Sandmo, Agnar (1990). "A Note on the Structure of Optimal Taxation". Oxford Economic Papers 42, pp. 78-90.

[31] Uppenberg, Kristian and Hubert Strauss (2010). "Innovation and Productivity Growth in the EU Service Sector". EIB Economic Surveys, No.2, European Investment Bank, Luxemburg. 


\section{A Appendix}

\section{A.1 First order conditions in the Ramsey problem}

For $t \geq 1$ the first order conditions in the Ramsey problem in (22) with respect to $h_{g, t}, h_{n, t}, k_{g, t}$, $k_{s, t}$ and $k_{n, t}$ are given by

$$
\begin{gathered}
0=\frac{(1-\alpha) u_{s_{m, t}} s_{m, t}}{h_{g, t}}-\frac{\varphi_{1}\left(1+k_{s, t} / k_{g, t}\right)}{1-h_{m, t}-h_{n, t}}+u_{c, t}(1-\alpha) k_{g, t}^{\alpha} h_{g, t}^{-\alpha}-\chi_{t} u_{h_{n, t}, h_{g, t}} \\
+\Phi \frac{\partial}{\partial h_{g, t}}\left(u_{s_{m, t}} s_{m, t}+u_{k_{n, t}} k_{n, t}-u_{l, t} h_{g, t}\left(1+k_{s, t} / k_{g, t}\right)\right) ;
\end{gathered}
$$

$$
\chi_{t}=\frac{\Phi}{u_{h_{n, t} h_{n, t}}} \frac{\partial}{\partial h_{n, t}}\left[u_{s_{m, t}} k_{s, t}\left(h_{g, t} / k_{g, t}\right)^{1-\alpha}+u_{k_{n, t}} k_{n, t}-u_{l, 1} h_{m, t}\right]
$$

$$
\begin{aligned}
& (1-\alpha) \frac{u_{s_{m, t+1}} s_{m, t+1}}{k_{g, t+1}}=\frac{\varphi_{1} h_{g, t+1}}{1-h_{m, t+1}-h_{n, t+1}} \frac{k_{s, t+1}}{k_{g, t+1}^{2}}+u_{c_{t+1}} \alpha k_{g, t+1}^{\alpha-1} h_{g, t+1}^{1-\alpha}+u_{c_{t+1}}(1-\delta)-\chi_{t+1} u_{h_{n, t+1}, k_{g, t+1}} \\
& -\frac{u_{c t}}{\beta}+\Phi \frac{\partial}{\partial k_{g, t+1}}\left[u_{s_{m, t+1}} k_{s, t+1}\left(h_{g, t+1} / k_{g, t+1}\right)^{1-\alpha}+u_{k_{n, t+1}} k_{n, t+1}-u_{l, t+1} h_{g, t+1}\left(1+k_{s, t+1} / k_{g, t+1}\right)\right] ;
\end{aligned}
$$

$(30)$

$$
\begin{gathered}
0=\frac{u_{s_{m, t+1}} s_{m, t+1}}{k_{s, t+1}}-\frac{\varphi_{1} h_{g, t+1} / k_{g, t+1}}{1-h_{m, t+1}-h_{n, t+1}}-\frac{u_{c t}}{\beta}+u_{c_{t+1}}(1-\delta)-\chi_{t+1} u_{h_{n, t+1}, k_{s, t+1}} \\
+\Phi \frac{\partial}{\partial k_{s, t+1}}\left[u_{s_{m, t+1}} k_{s, t+1}\left(h_{g, t+1} / k_{g, t+1}\right)^{1-\alpha}+u_{k_{n, t+1}} k_{n, t+1}-u_{l, t+1} h_{g, t+1}\left(1+k_{s, t+1} / k_{g, t+1}\right)\right]
\end{gathered}
$$




$$
\begin{gathered}
u_{k_{n, t+1}}=\frac{u_{c, t}}{\beta}-u_{c_{t+1}}\left(1-\delta_{n}\right)+\chi_{t+1} u_{h_{n, t+1}, k_{n, t+1}} \\
-\Phi \frac{\partial}{\partial k_{n, t+1}}\left[u_{s_{m, t+1}} k_{s, t+1}\left(h_{g, t+1} / k_{g, t+1}\right)^{1-\alpha}+u_{k_{n, t+1}} k_{n, t+1}\right]
\end{gathered}
$$

where $u_{x_{t}, z_{t}}$ is the derivative of the utility function w.r.t. $x_{t}$ and $z_{t}$. To obtain the first-order conditions for period 0 , add $-\Phi V_{c}^{0} / \beta$ to the r.h.s. of equations (29)-(30), add $\Phi V_{c}^{0} / \beta$ to the r.h.s of (31) and subtract $\Phi V_{h_{g}}^{0}$ from the r.h.s. of equation (27). ${ }^{40}$

The term $\bar{\Phi}$ that is referred to in section 3 is defined as $\bar{\Phi} \equiv \Phi\left(1+\Omega_{1}\right) /(1-\eta)$, where $\Omega_{1}$ is given by $\Omega_{1} \equiv \frac{\partial}{\partial h_{n, t}}\left[u_{s m, t} s_{m, t}+u_{k, n, t} k_{n, t}-u_{l, t} h_{m, t}\right]\left(h_{n, t} u_{h_{n, t} h_{n, t}}\right)^{-1}$. Hence, $\bar{\Phi}$ is proportional to $\Phi$, but it also takes the general-equilibrium effects of home production on the life-time budget constraint into account. Specifically, in general equilibrium the level of home production affects the total level of market resources, i.e., the total amount of market services, home capital as well as total labor income. The variable $\Omega_{1}$ can be shown to be strictly positive and strictly increasing in $\varepsilon$.

\section{A.2 Numerical Computation}

The algorithm that is used to find the equilibrium starts by fixing the initial tax rates on market and home capital, $\tau_{0}^{k_{m}}$ and $\tau_{0}^{k_{n}}$. The next step is to make a guess on a multiplier $\Phi$ and solve for the transition using the equations specified in Section 2.5. The third step is to check whether the adjusted budget constraint holds with equality; otherwise the multiplier has to be updated. When the allocation has been found, the interest rate and tax rates are computed from the agent's first-order conditions.

\footnotetext{
${ }^{40} V^{0}$ is given by (??) and $V_{X}^{0}$ then referrs to the derivative of $V^{0}$ with respect to $X$.
} 


\section{A.3 Estimating average effective tax rates}

The approach developed by Mendoza et al. (1994) is used to estimate current tax rates on labor, consumption, services and capital. The idea is to relate realized tax rates directly to the relevant macroeconomic variables in the National Accounts. Resulting estimates are known as average effective tax rates (AETR), and are consistent with the concept of aggregate tax rates at the national level and with the representative agent framework. The tax revenue data are taken from the OECD Revenue Statistics database, which contains information on tax revenues as reported by member countries. Estimates of the value of the associated tax bases are from the OECD National Accounts database.

Table 7: Variable names and symbols used

Revenue Statistics:
$1100=$ Taxes on income, profit and capital gains of individuals or households
$2000=$ Total social security contributions
$2200=$ Social security contributions paid by employers
$3000=$ Taxes on payroll and workforce
$4000=$ Taxes on property
$4100=$ Recurrent taxes on immovable property
$4400=$ Taxes on financial and capital transactions
$5110=$ General taxes on goods and services
$5121=$ Excise taxes
National Accounts:
CP $=$ Household final consumption expenditure
CG $=$ Government final consumption expenditure
OS = Net operating surplus of the overall economy
OSPUE = Households' unincorporated operating surplus
PEI = Households' property income
S = Household consumption expenditures on services
W = Wages and salaries

In the U.S., tax rates on services are basically zero. ${ }^{41}$ Using this as an assumption, the tax rate

\footnotetext{
${ }^{41}$ Isaacson and Bertoni (2000).
} 
on consumption goods in the U.S. can then be calculated by deducting the amount households and the government spend on services from the tax base. In Europe in contrast, supplies of goods and services are both subject to a standard tax rate of at least 15 percent. I thus assume European tax rates on goods and services to be equal when calculating these tax rates. The AETRs on consumption goods and services are then given by

$$
\tau_{U S}^{c}=\frac{5110+5121}{C P+C G-S-5110-5121} \quad \text { and } \quad \tau_{E U}^{c}=\tau_{E U}^{s}=\frac{5110+5121}{C P+C G-5110-5121}
$$

The approach to calculating AETRs on labor and on capital is to begin by calculating the AETR on total household income, $\tau^{i}$, and then use this measure to compute the labor tax rate, $\tau^{h}$ :

$$
\tau^{i}=\frac{1100}{O S P U E+P E I+W} \quad \text { and } \quad \tau^{h}=\frac{\tau^{i} W+2000+3000}{W+2200} .
$$

Capital taxes are then finally given by

$$
\tau^{k_{m}}=\frac{\tau^{i}(O S P U E+P E I)+1200+4100+4400}{O S} .
$$

\section{A.4 Graphs}

The transition in the benchmark calibration is displayed in Figure 1, and associated optimal tax rates are displayed in Figure 2. 

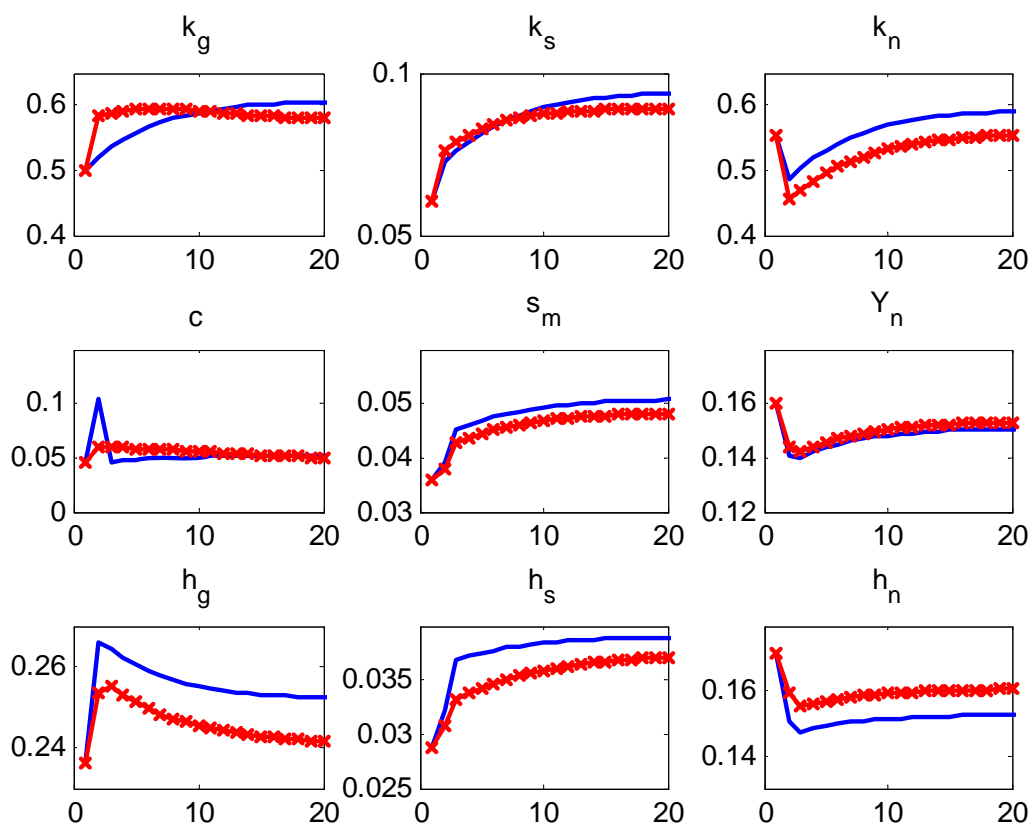

Figure 1: Inputs and outputs in the three sectors in the transitions. The solid lines denote the benchmark case and the dashed lines denote the case where the capital tax is not allowed to be increased. 

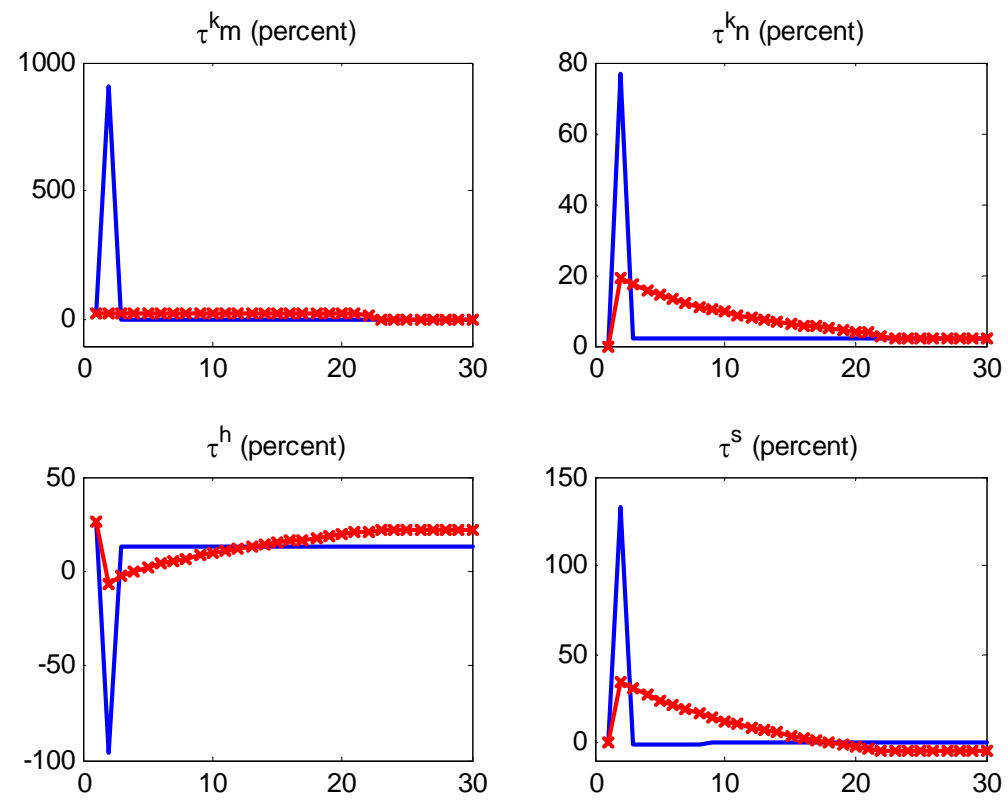

Figure 2: The optimal path for tax rates on capital, home capital, labor and services in the U.S. The solid lines denote the benchmark case and the dashed lines denote the case where the capital tax is not allowed to be increased. 